\title{
DUKUNGAN KELUARGA BERHUBUNGAN DENGAN KECERDASAN EMOSIONAL REMAJA
}

\author{
Dwi Yuniar ${ }^{1}$, Irma Darmawati ${ }^{2}$ \\ ${ }^{1,2}$ Sekolah Tinggi Ilmu Keperawatan PPNI Jawa Barat \\ Jl. Muhammad No. 34A Bandung 40173 \\ Telp. 022-6004498, 022-6121914, Fax.022-6121914 \\ Email:irma_darmawati87@yahoo.com
}

\begin{abstract}
Abstrak
Kondisi remaja saat ini cukup mengkhawatirkan. Prevalensi ketidakstabilan emosi remaja pada tahun 2015 di kota Bandung mencapai $40 \%$. Keluarga merupakan faktor yang dapat mempengaruhi terhadap kecerdasan emosional remaja, dengan adanya dukungan dari keluarga dapat membantu remaja memperoleh kecerdasan emosional yang tinggi. Penelitian ini dilakukan untuk mengetahui adanya hubungan antara dukungan keluarga dengan kecerdasan emosional remaja di SMA kota Bandung. Penelitian ini menggunakan desain deskriptif korelasi dengan pendekatan cross sectional dengan metode cluster sampling dan didapatkan 170 sampel. Data dianalisis menggunakan non-parametrik Uji Spearman. Berdasarkan hasil analisis statistik diperoleh $27,1 \%$ remaja yang kurang mendapatkan dukungan dari keluarga memiliki kecerdasan emosional dalam kategori rendah dan $31,2 \%$ remaja yang memperoleh dukungan dari keluarga memiliki kecerdasan emosional dalam kategori tinggi. Hasil uji Spearman menunjukan $p$-value 0,033 ( $\mathrm{p}$ $0,05)$ r 0,163 . H0 ditolak yang artinya ada hubungan yang sangat rendah antara dukungan keluarga dengan kecerdasan emosional remaja di SMA kota Bandung. Hasil penelitian ini diharapkan dapat meningkatkan motivasi perawat untuk melakukan promosi kesehatan mengenai psikologis remaja melalui program Bina Keluarga Remaja, Program Kesehatan Peduli Remaja, dan Usaha Kesehatan Sekolah.
\end{abstract}

Kata kunci : ketidakstabilan emosi remaja, kecerdasan emosional dan dukungan keluarga

\begin{abstract}
Teenager is in worrying condition. Emotional intelligence of adolescents' emotional instability on 2015 in Bandung reaches $40 \%$. Family is a factor which can influence the emotional intelligence of adolescents, support of the family can help adolescent to acquire high emotional intelligence. Purpose of this study was to determine the relationship between family support with emotional intelligence of adolescent in senior high school at Bandung. Using a descriptive correlation with cross sectional approach, using cluster sampling method and 170 person involved in this study. Data analysis by non-parametric Spearman test. Based on the result of statistical analysis describe $27.1 \%$ of adolescent who were lack of support from their families has allow emotional intelligence the other side $31.2 \%$ of adolescence who receive support from their families has a high emotional intelligence. Spearman's test results show a p-value of 0,033 $(p<0,005) r 0,163$. Which means there is a very low correlation between family support with emotional intelligence of adolescents in Bandung high school. It's expected that nursing's motivation to did health promotion about adolescent pshycologis with programme BKR, PKRR, PKPR and UKS.
\end{abstract}

Keywords: adolescent emotional instability, emotional intelligence and family support 


\section{PENDAHULUAN}

Remaja merupakan tahap paling penting dalam kehidupan seseorang, dalam tahap ini tugas perkembangan yang paling sulit dicapai yaitu kematangan emosi (Yusuf, 2015). Sesuai dengan penelitian yang dilakukan oleh Nur dan Ekasari (2008) pada masa remaja sering kali diwarnai dengan ketidakstabilan emosi dalam menghadapi ketidaknyamanan emosional tersebut tidak sedikit remaja mengalami depresi yang ditunjukan dengan tindakan kenakalan remaja sehingga untuk menghadapinya mereka menutupinya dengan cara maladjusment seperti agresif seperti, berkelahi dan senang mengganggu, melawan, keras kepala, dan melarikan diri seperti dari kenyataan, melamun, pendiam atau senang menyendiri, menggunakan obat terlarang atau minum-minuman keras dan tawuran (Yusuf, 2015).

Ratusan ribu pelajar sering terlibat tawuran. Pada tahun 2012 terdapat 250 kasus tawuran dan menawaskan korban sebanyak 37 pelajar dan mengalami peningkatan pada tahun 2013 yaitu sebanyak 339 kasus tawuran dan 82 diantaranya meninggal dunia dan terus mengalami peningkatan pada tahun 2014 mencapai 643 kasus tawuran (Markas Resor Kota Besar Bandung, 2016). Miras pada pelajar sekolah swasta juga cukup mengkhawatirkan. Pada tahun 2014 sebesar $23 \%$ remaja yang mengkonsumsi minuman keras sedangkan pada tahun 2010 hanya mencapai $4,9 \%$ yang mengkonsumsi minuman keras, peningkatan yang signifikan dari tahun sebelumnya, selain itu pada tahun 2016, sejumlah 56 pelajar SMK swasta di Kota Subang mengadakan pesta kelulusan dengan mengkonsumsi minuman keras (Detikcom, 2016).

Data-data diatas merupakan bentuk dari kenakalan remaja yang saat ini. Kenakalan remaja (juvenile deliquency) merupakan salah satu problem lama yang terjadi dikarenakan seorang remaja mengalami ketidakstabilan emosi. Yusuf (2015) berpendapat bahwa kestabilan emosi dipengaruhi oleh kurangnya dukungan keluarga yang diperoleh remaja. Kurangnya dukungan keluarga yang diperoleh remaja maka akan menjadikan remaja mengalami ketidaknyamanan emosi (Yusuf, 2015). Berbeda dengan remaja yang memperoleh dukungan dari keluarga. Remaja yang memperoleh dukungan dari orang tua dapat membantu remaja memperoleh kematangan emosi yang ditandai dengan konsep diri remaja yang baik. Penelitian yang dilakukan oleh penelitian yang dilakukan oleh Salam, Suharsono, dan Amogo (2011) mengenai dukungan keluarga terhadap konsep diri remaja menyatakan bahwa remaja yang mendapatkan dukungan keluarganya tinggi akan memiliki konsep diri yang positif. Konsep diri yang baik akan menjadikan remaja sehat secara emosi dan hal ini akan berdampak baik untuk kematangan emosi dan menjadikan remaja memperoleh kecerdasan emosional yang tinggi.

Kecerdasan emosional merupakan kemampuan remaja mengetahui perasaan sendiri, mampu untuk mengelola emosinya, memiliki motivasi yang tinggi dan peduli terhadap orang lain sehingga ia dapat hidup dengan orang lain dan menjadikan remaja sukses di masa yang akan datang. Goeleman (2015) berpendapat bahwa remaja yang mempunyai kecerdasan emosional akan terhindar dari perilaku-perilaku menyimpang seperti seks bebas, narkoba, tawuran dan minum-minuman keras. Penelitian yang dilakukan oleh Sabiq dan Djalali (2012) menyatakan bahwa remaja yang mempunyai kecerdasan emosional tinggi akan berperilaku prososial tinggi pula dan sebaliknya mereka yang kecerdasan emosionalnya rendah akan 
menyebabkan perilaku prososial yang rendah pula. Penelitian lain yang dilakukan oleh Aprilia dan Indrijati (2014) memperkuat penelitian sebelumnya bahwa remaja yang memiliki kecerdasan emosional tinggi maka akan terhindar dari perilaku tawuran sedangkan remaja yang memiliki kecerdasan emosional yang rendah maka akan terlibat tawuran.

Hasil wawancara yang dilakukan oleh peneliti kepada Dinas Pendidikan Kota Bandung didapatkan bahwa sekolah swasta memiliki tingkat kenakalan remaja yang lebih tinggi dibandingkan dengan sekolah negeri. Sejalan dengan hasil studi pendahuluan di beberapa SMA swasta di kota Bandung didapatkan bahwa $83,3 \%$ remaja pernah membolos, $86,67 \%$ anak pernah menonton video porno, $66,67 \%$ anak pernah melakukan perkelahian, $40 \%$ anak pernah minum-minuman keras dan peneliti mendapatkan informasi dari beberapa sekolah setiap tahun ada anak yang dikeluarkan atau DO (Drop Out) dikarenakan hamil di luar nikah dan masalah kedisiplinan lainnya yang berkaitan dengan kecerdasan emosional remaja. Selain itu, peneliti juga mendapatkan informasi dari salah satu petugas sekolah bahwa di salah satu sekolah SMA yang ada di kota Bandung pernah ada anak yang melakukan hubungan seks di lingkungan sekolah. Berdasarkan data tersebut dikajilah hubungan antara dukungan keluaga dengan kecerdasan emosional remaja sma di kota Bandung.

\section{METODE PENELITIAN}

Penelitian ini menggunakan desain deskripstif korelasi dengan pendekatan Cross Sectional, dengan menggunakan metode Cluster sampling sehingga didapatkan lima sekolah SMA di Kota Bandung yaitu SMA YPI, SMA PGRI I, SMA PGRI III, SMA Taman Siswa dan SMA YWKA. Adapun teknik pengambilan sampel menggunakan random sampling dengan jumlah responden sebanyak 170 responden pada siswa kelas 2 SMA yang masih memiliki orang tua dan tinggal bersama kedua orang tua.

Alat ukur yang dugunakan yaitu kuesioner yang telah diujicobakan terlebih dahulu dan telah dinyatakan valid dan reliabel. Untuk melihat hubungan diantara kedua variabel peneliti menggunakan uji statistik Spearman.

\section{HASIL DAN PEMBAHASAN}

Tabel 1.

Hubungan antara Dukungan Keluarga dengan Kecerdasan Emosional Remaja SMA di Kota Bandung, Maret 2016

\begin{tabular}{cccccc}
\hline \multirow{2}{*}{ Dukungan Keluarga } & \multicolumn{3}{c}{ Kecerdasan Emosional } & \multirow{2}{*}{ Pendah } & \multicolumn{2}{c}{ Tinggi } & \multirow{2}{*}{ P Value } \\
\cline { 2 - 5 } & $\mathbf{n}$ & $\mathbf{\%}$ & $\mathbf{n}$ & $\mathbf{\%}$ & \\
\hline Kurang Mendukung & 46 & 27.1 & 35 & 20.5 & \multirow{2}{*}{0,033} \\
Mendukung & 36 & 21.2 & 53 & 31.2 & \\
\hline Total & $\mathbf{8 2}$ & $\mathbf{4 8 . 3}$ & $\mathbf{8 8}$ & $\mathbf{5 1 . 7}$ & \\
\hline
\end{tabular}


Hasil analisis yang telah peneliti lakukan menggunakan uji statistik Spearman didapatkan bahwa ada hubungan antara dukungan keluarga dengan kecerdasan emosional remaja SMA di Kota Bandung dengan hasil uji korelasi Spearman yaitu pvalue $=0,033<\alpha(0.05)$ dengan nilai hubungan 0,163 yang berarti $\mathrm{H} 0$ ditolak yang artinya ada hubungan antara dukungan keluarga dengan kecerdasan emosional remaja dengan nilai korelasi sangat rendah dan bernilai positif maka korelasi searah, dimana semakin besar dukungan keluarga yang diperoleh maka semakin tinggi pula kecerdasan emosional yang dimiliki oleh remaja.

Sejalan dengan temuan peneliti yang dapat dilihat pada tabel 1. diketahui bahwa remaja SMA di Kota Bandung yang kurang memperoleh dukungan dari keluarga hampir setengahnya memiliki kecerdasan emosional rendah yaitu sebanyak 46 orang atau $27.1 \%$ dan $21.2 \%$ (36 orang) yang memperoleh dukungan dari keluarga memiliki kecerdasan emosional yang rendah.

Hasil analisis yang telah peneliti lakukan menggunakan uji statistik Spearman didapatkan bahwa ada hubungan antara dukungan keluarga dengan kecerdasan emosional remaja SMA di Kota Bandung dengan hasil uji korelasi Spearman yaitu pValue $=0,033<\alpha(0.05)$ dengan nilai hubungan 0,163 yang berarti H0 ditolak yang artinya ada hubungan antara dukungan keluarga dengan kecerdasan emosional remaja dengan nilai korelasi yang sangat rendah dan bernilai positif maka korelasi searah, dimana semakin besar dukungan yang diperoleh maka semakin tinggi pula kecerdasan emosional yang dimiliki oleh remaja. Sejalan dengan temuan peneliti diketahui bahwa remaja SMA di Kota Bandung yang kurang memperoleh dukungan dari keluarga hampir setengahnya memiliki kecerdasan emosional rendah yaitu sebanyak 46 orang atau $27.1 \%$ dan $21.2 \%$ (36 orang) yang memperoleh dukungan dari keluarga memiliki kecerdasan emosional yang rendah.

Sejalan dengan penelitian yang dilakukan oleh Bakar (2007) mengenai hubungan keluarga, teman sebaya dan kecerdasan emosional dengan perilaku deliquen remaja yang mendapatkan hasil bahwa terdapat hubungan antara keluarga dengan kecerdasan emosional remaja yang bersifat positif dengan kekuatan korelasi lemah. Dukungan keluarga merupakan bentuk perhatian dan kasih sayang yang diberikan keluarga khususnya orang tua kepada anggota keluarga dimana dalam hal ini dapat mempengaruhi terhadap mental remaja.

Sejalan dengan penelitian yang dilakukan oleh Anastika dan Soeharto (2013) mengenai dukungan keluarga dengan kesehatan mental remaja bahwa ada kontribusi yang signifikan dari dukungan orang tua terhadap kesehatan mental siswa. Sehat mental berarti sehat secara psikis didalamnya termasuk sehat secara emosi sehingga remaja mampu untuk mengelola emosinya. Penelitian yang sama dilakukan oleh Helfrich (2014) menyatakan bahwa dukungan keluarga berpengaruh terhadap kesehatan mental remaja baik pengaruh yang positif maupun negatif.

Remaja yang memperoleh dukungan yang negatif dari keluarga akan berdampak kurang baik terhadap emosi remaja. Sejalan dengan penelitian yang dilakukan oleh Susanto, Sulastri, dan Listyorini (2013) didapatkan bahwa remaja yang mendapatkan dukungan negatif dari keluarga akan menghasilkan perilaku negatif pula, penelitian ini mendapatkan hasil bahwa remaja yang memproleh dukungan negatif dari keluarga berpengaruh terhadap perilaku merokok remaja. Sejalan dengan penelitian yang 
dilakukan oleh Mutia dan Kumolohadi (2005) yang menyatakan bahwa dukungan informasi yang kurang memadai dari orang tua dapat menyebabkan remaja mencari informasi dari luar yang akan berpengaruh terhadap kenakalan remaja.

Bentuk dukungan keluarga lainnya yaitu dukungan emosional seperti fungsi afektif keluarga. Penelitian yang dilakukan oleh Kusumaningrum, Trilonggani dan Nurhalinah (2011) mengenai fungsi afektif keluarga dengan kecerdasan emosional remaja yang mendapatkan hasil bahwa terdapat hubungan antara fungsi afektif keluarga dengan kecerdasan emosional remaja. Selain itu, terdapat penelitian lain mengenai dukungan keluarga dengan self regulated learning yaitu gabungan antara kemampuan sosioemosional yaitu kemampuan untuk memonitor perasaan sendiri dan membina hubungan dengan teman sebaya dan mampu memahami situasi dan kondisi saat ini. Dalam penelitiannya mendapatkan hasil bahwa terdapat hubungan antara dukungan keluarga dengan self regulated learning dimana semakin tinggi dukungan sosial keluarga maka self regulated learning semakin tinggi dan sebaliknya apabila dukungan sosial keluarga yang diperoleh remaja rendah maka self regulated learning pun semakin rendah. Hal ini sesuai dengan yang kemukakan oleh Goeleman (2015) bahwa keluarga mempunyai pengaruh terhadap kecerdasan emosional seseorang.

Hasil penelitian ini ditemukan korelasi yang sangat lemah antara dukungan keluarga dengan kecerdasan emosional remaja, hal ini dapat dipengaruhi oleh faktor lain seperti otak, jenis kelamin, usia, dukungan sosial, lingkungan sekolah dan lingkungan keluarga. Lingkungan keluarga merupakan sekolah pertama bagi setiap anak didalam keluarga anak akan mempelajari emosi, tetapi apabila orang tua tidak mampu atau salah dalam mengenalkan emosi, maka dampaknya akan sangat fatal terhadap anak (Goleman, 2007).

Penelitian yang dilakukan oleh Indriato (2012) mendapatkan hasil bahwa lingkungan keluarga yang baik atau hangat akan menjadikan remaja sehat secara emosi. Sejalan dengan penelitian yang dilakukan oleh Munawaroh (2012) mengenai intensitas komunikasi orang tua dan anak dalam penelitiannya mendapatkan hasil bahwa kecenderungan remaja melakukan hubungan seks pranikah dapat diakibatkan oleh kurangnya intensitas komunikasi orangtua dengan anak. Apabila lingkungan keluarga kondusif maka akan dapat membantu remaja untuk membangun karakter remaja ke arah yang lebih baik sehingga mampu untuk memiliki kecerdasan emosional yang tinggi. Pembangunan karakter anak sejak dini didapat dari pola asuh keluarga. Pola asuh yang baik dapat membantu remaja memperoleh karakter yang baik bagi remaja dan memperoleh kecerdasan emosional yang tinggi.

Penelitian yang dilakukan oleh Arisandi dan Latiffah (2007) mengenai gaya pengasuhan orang tua didapatkan bahwa terdapat hubungan yang signifikan antara gaya pengasuhan orang tua dengan kecerdasan emosional anak remaja, sehingga semakin baik gaya pengasuhan keluarga maka semakin tinggi kecerdasan emosional remaja. Hal ini berbeda dengan penelitian yang dilakukan oleh Purwanti (2013) mengenai pola asuh dengan kematangan emosi mengatakan bahwa keluarga tidak memiliki pengaruh terhadap perkembangan emosi seseorang.

Sejalan dengan penelitian yang dilakukan oleh Asyik, Ismanto dan Babakal (2014) mengenai pola asuh dengan kecerdasan emosional remaja. Pada penelitiannya mendapatkan hasil bahwa tidak terdapat hubungan antara pola asuh keluarga dengan 
kecerdasan emosional remaja. Tidak terdapatnya hubungan dalam penelitian tersebut dapat disebabkan oleh faktor lain yaitu otak, dukungan sosial, lingkungan sekolah, jenis kelamin dan usia.

Usia dapat berpengaruh terhadap kecerdasan emosional seseorang. Goeleman (2015) berpendapat bahwa semakin lama seseorang hidup maka semakin banyak pengalaman yang diperoleh dan akan semakin baik dalam mengelola emosinya. Sejalan dengan hasil yang didapatkan oleh Kusumaningrum, Trilonggani dan Nurhalinah (2011) terhadap siswa SMA dengan usia remaja pada rentang usia 16 tahun bahwa hampir seluruhnya memiliki kecerdasan emosional dalam kategori tinggi. Hal ini diperkuat oleh Sari (2011) bahwa kematangan emosi berada pada rentang usia 16-18 tahun dalam penelitian tersebut sudah tidak ada lagi remaja yang kematangan emosinya masih rendah.

Selain usia jenis kelamin juga dapat berpengaruh. Hamid, M. (2007) berpendapat bahwa terdapat perbedaan kecerdasan emosional perempuan dengan laki-laki sejalan dengan penelitian yang dilakukan oleh Portillo (2011) pada pelajar mendapatkan hasil bahwa terdapat perbedaan kecerdasan emosional remaja laki-laki dan perempuan namun tidak terlalu signifikan. Rendahnya korelasi tersebut dapat dikarenakan oleh faktor lain yaitu intelektual, lingkungan sekolah dan dukungan sisoal salah satunya yaitu teman sebaya.

Penelitian yang dilakukan oleh Nurmalasari (2013) mengenai teman sebaya dengan kecerdasan emosional mendapatkan hasil bahwa terdapat hubungan yang kuat antara teman sebaya dengan kecerdasan emosional remaja. Sejalan dengan penelitian yang dilakukan oleh Ammar (2014) bahwa terdapat hubungan yang signifikan antara teman sebaya dengan kecerdasan emosional remaja.
Teman sebaya merupakan bagian yang cukup penting pada masa remaja. Dimana pada tahap ini remaja lebih banyak menghabiskan waktu dengan teman sebaya dibandingkan dengan orang tua (Agustiani 2009).

Santrock (2009) berpendapat bahwa pada tahap remaja hubungan dengan orang tua mengalami perubahan dan cenderung terjadi konflik dimana orang tua masih menganggap mereka masih kecil. Sejalan dengan yang kemukakan oleh Erikson (1968) dalam Santrock (2009) bahwa remaja dalam keadaan bingung peran dimana dalam hal ini remaja belum bisa dikatakan dewasa dan bukan lagi berada pada masa kanak-kanak sehingga sering terjadi permasalahan dimana remaja mengalami krisis identitas. Penelitian yang dilakukan oleh Bakar (2007) mengenai hubungan keluarga, teman sebaya dan kecerdasan emosional dengan perilaku deliquen remaja yang mendapatkan hasil bahwa tidak terdapat hubungan antara teman sebaya dengan kecerdasan emosional remaja. Selain faktor dukungan sosial yaitu teman sebaya lingkungan sekolah juga dapat berpengaruh terhadap kecerdasan emosional seseorang.

Sekolah merupakan lembaga pendidikan formal yang secara sistematis, melaksanakan program bimbingan, pengajaran, dan latihan mengembangkan potensinya baik yang menyangkut aspek moral-spiritual intelektual, emosional maupun sosial (Amirulloh, 2015). Sejalan dengan yang dikemukakan oleh Pitriani, Latiffah dan Guhardja (2008) bahwa sekolah dapat menciptakan lingkungan yang mempunyai disiplin yang baik, memberikan pembelajaran emosional dengan mengadakan kegiatan ektrakurikuler dan adanya hubungan guru-siswa yang baik. Hasil penelitiannya menyatakan bahwa terdapat hubungan antara lingkungan sekolah baik pembelajaran kedisiplinan, kegiatan ekstrakurikuler dan 
hubungan guru-siswa dengan kecerdasan emosional remaja.

Penelitian yang dilakukan oleh Nadia (2013) sejalan dengan penelitian di atas mengenai hubungan antara guru Pancasila dengan kecerdasan emosional remaja didapatkan bahwa terdapat hubungan antara pembelajaran mengenai pendidikan Pancasila yang dilakukan oleh guru Pancasila dengan kecerdasan emosional remaja. Penelitian lain yang dilakukan oleh Rahim dan Smith (2013) mengenai atmosfir sekolah terhadap kecerdasan emosional didapatkan bahwa kecerdasan emosional dapat dikembangkan melalui pendidikan di sekolah, apabila kondisi lingkungan sekolah memadai maka akan membantu dalam meningkatkan kecerdasan emosional remaja namun apabila keadaan sekolahnya kurang memadai maka akan menyebabkan kecerdasan emosional remaja rendah.

\section{PENUTUP}

\section{Kesimpulan}

Berdasarkan hasil analisis dan hasil pengujian hipotesis penelitian bahwa dapat disimpulkan sebagai berikut:

Terdapat hubungan yang sangat rendah antara dukungan keluarga dengan kecerdasan emosional remaja SMA di Kota Bandung dengan $\mathrm{p}$ value 0,033 ( $\mathrm{p}<0,05)$ r 0,163 yang bernilai positif maka semakin tinggi dukungan keluarga yang diperoleh maka semakin tinggi pula kecerdasan emosional remaja.

\section{Saran Praktis}

1. Saran bagi bidang keperawatan

Hasil penelitian dapat di realisasikan dan memotivasi perawat untuk melakukan promosi kesehatan mengenai kesehatan remaja khususnya kesehatan psikologis remaja melalui program-program puskesmas seperti Bina Keluarga Remaja, Program Kesehatan Peduli Remaja, dan dapat bekerja sama dengan sekolah yaitu melalui program Usaha Kesehatan Sekolah.

\section{Saran bagi sekolah}

Hasil penelitian ini dapat menjadikan sekolah untuk dapat memperhatikan kecerdasan emosional siswa di sekolah dan tidak hanya berfokus terhadap kecerdasan intelektual siswa saja. Dengan cara dapat menambah pelajaran pengenalan emosi di pelajaran bimbingan konseling, dengan Bermain peran (rolle play), pelatihan kepramukraan dan dengan cara menanamkan rasa tolong menolong sesama manusia yaitu dengan bakti sosial serta adanya kerjasama dengan orang tua dengan mengadakan pertemuanpertemuan guna membahas mengenai perkembangan remaja.

\section{Saran bagi orang tua}

Orang tua merupakan pendidik pertama bagi setiap anak, sehingga hasil penelitian ini, orang tua dapat memberikan dukungan yang tinggi bagi setiap anaknya untuk memperoleh khususnya kecerdasan emosional yang merupakan salah satu kunci sukses bagi remaja dimasa yang akan datang. Diharapkan orang tua dapat menanamkan sikap kerja sama dengan anak dalam berbagai kegiatan guna untuk meningkatkan pengelolaan emosi dan meningkatkan motivasinya.

\section{Saran bagi penelitian selanjutnya}

Hasil dari penelitian ini di harapkan agar menjadi inspirasi bagi peneliti selanjutnya untuk melakukan penelitian mengenai kecerdasan emosional remaja yang dapat dilihat dari faktor lain yang tidak di bahas oleh peneliti seperti intelektual, jenis kelamin, usia, dukungan sosial, lingkungan sekolah dan lingkungan keluarga. 
DAFTAR PUSTAKA

Agustiani, H. (2009). Psikologi Perkembangan (Pendekatan Ekologi Kaitannya dengan Konsep Diri dan Penyesuaian Diri pada Remaja). Bandung: PT Refika Aditama.

Amirulloh. (2015). Teori Pendidikan Karakter Remaja dalam Keluarga. Bandung: Alfabeta.

Ammar, A. M. (2014). Hubungan Antara Interaksi Teman Sebaya dengan Kecerdasan Emosional. 21-115.

Anastika, F., \& Soeharto. (2013). Kontribusi Dukungan Orang Tua terhadap Kesehatan Mental Siswa Kelas IX SMA Negeri 2 Sukoharjo Tahun Pelajaran 2013/2014, 1-12.

Aprilia, N., \& Indrijati, H. (2014). Hubungan Antara Kecerdasan Emosional dengan Perilaku Tawuran pada Remaja Lakilaki yang Pernah Terlibat Tawuran di SMK B Jakarta. Jurnal Psikologi Pendidikan dan Perkembangan Vol. 3 No. 1 April 2014, 1-11.

Arisandi, R., \& Latiffah, M. (2007). Analisis Persepsi Anak terhadap Gaya Pengasuhan Orang Tua, Kecerdasan Emosional, Aktivitas dan Prestasi Belajar Siswa Kelas XI di SMAN 3 Sukabumi.

Asyik, F. M., Ismanto, A. Y., \& Babakal, A. (2014). Hubungan Pola Asuh Orang Tua dengan Kecerdasan Emosional Pada Anak Usia Remaja di Kelurahan Soasio Kota Tidore Kepulauan. ejournal keperawatan (e-Kp) Volume 3 Nomor 2, 1-6.

Bakar, M. A. (2007). Perkaitan antara Hubungan Keluarga, Pengaruh teman Rekan Sebaya dan Kecerdasan
Emosional dengan Tingkah Laku Delinkuen Pelajar . 20-65.

Dariyo, A. (2015). Keterampilan Organisasi, Kecerdasan Emosional dan Persahabatan. Seminar Psikologi dan Kemanusiaan 2015 Psychology Forum UMM ISBN : 978-979-324-8, 15-20.

Goeleman, D. (2007). Emosional Intellegence Terjemahan Mengapa EQ Lebih Penting daripada IQ. Jakarta: PT Gramedia Pustaka Utama.

Goeleman, D. (2015). Emotional Intelligence Mengapa EI Lebih Penting Daripada IQ. Jakarta: PT Gramedia .

Hamid, M. A. (2007). EQ : Panduan Meningkatkan Kecerdasan Emosi. Kuala Lumpur: PTS Professional Publishing.

Handayani, A., Widiharto, C. A., \& Mulia, D. (2010). Perilaku Seksual Remaja ditinjau dari Dukungan Sosial Orang Tua dan Konsep Diri. 2-18.

Harnilawati. (2013). Konsep dan Proses Keperawatan Keluarga. Sulawesi Selatan: Pustaka As Salam.

Helfrich, C. (2014). The Relationship Between Adolescent Mental Health, Parental Depression And Family Environment For Adolescent Accessing Intensive Mental Health Treatment. 1-91.

Indriato, PP, G. N. (2012). Hubungan Lingkungan Sekolah, Keluarga, dan Masyarakat terhadap Karakter Siswa SMK Negeri Kelompok Teknologi SeKabupaten Sleman. Skripsi, 1-167.

Kusumaningrum, A., Trilonggani, H., \& Nurhalimah. (2011). Hubungan Fungsi Afektif Keluarga terhadap Kecerdasan Emosional Remaja. 1-15. 
Munawaroh, F. (2012). Hubungan. Jurnal Pesona Psikologi Indonesia, Vol. 1 No. 2, 105-119.

Mutia, E. \& Kumolohadi, R. (2005). Hubungan Antara Dukungan Keluarga dengan Kecenderungan Kenakalan Remaja. 1-19

Nur, F. I., \& Ekasari, A. (2008). Hubungan Antara Konsep Diri dengan Kecerdasan Emosional pada Remaja. Jurnal Soul Vol. 1 No. 2, 15-31.

Nurmalasari, A. (2013). Hubungan Peran Teman Sebaya dengan Kecerdasan Emosional. Bandung: Skripsi (tidak diterbitkan).

Pitriani, W., Latiffah, M., \& Guhardja, S. (2008). Pengaruh Tipe Pengasuh, Lingkungan Sekolah, dan Teman Sebaya terhadap Kecerdasan Emosional Remaja. Vol. 1 No. 1, 4354.

Portillo, W. J. (2011). The Role of Emotional Intelligence in College Student's Succes. 1-116.

Purwanti, D. I. (2013). Hubungan Antara Pola Asuh Demokratis dengan Kematangan Emosi. 1-9.

Rahim, M., \& Smith, M. B. (2013). Hubungan Antara Atmosfir Sekolah dengan Kecerdasan Emosional Siswa SMK Negeri Gorontalo. 1-12.

Sabiq, Z., \& Djalali, M. A. (2012). Kecerdasan Emosional, Kecerdasan Spriritual dan Perilaku Prososial Santri Pondok Pesantren Nasyrul Ulum Pamekasan. Julnal Psikologi Vol 1 No 2, 53-65.

Safitri, E., \& Uyun, Q. (2007). Hubungan Kontrol Diri dengan Perilaku Seksual Remaja. 3-34.

Salam, M. N., Suharsono, \& Amogo, T. A. (2011). Hubungan Dukungan Keluarga dengan KOnsep Diri Remaja Kelas VIII SMPN 13 Depok Sleman Yogyakarta. 1-13.

Santrock, J. W. (2009). Remaja. Jakarta: PT Erlangga.

Sari, I. P. (2011). Hubungan Antara Keberfungsian Keluarga dengan Kematangan Emosi Remaja Laki-laki. Skripsi.

Susanto, D. N., Sulastri, B., \& Listyorini, D. (2013). Hubungan Dukungan Negatif Orang Tua dengan Perilaku Merokok Remaja di Desa Puro Kecamatan Karangmalang Seragen, 1-14.

Yusuf, L. (2015). Psikologi Perkembangan Anak dan Remaja. Bandung: PT. Remaja Rosdakarya. 